\title{
EFEKTIFITAS PEMBELAJARAN BERBASIS JOYFULL LEARNING DALAM MENINGKATKAN KOMPETENSI DASAR-DASAR DESAIN PADA SISWA KELAS X PAKET KEAHLIAN DKV SMK NEGERI PACITAN
}

\author{
MARDIYAH \\ SMK Negeri Pacitan
}

\begin{abstract}
Abstrak
Mata pelajaran Dasar-dasar Desain mempelajari tentang konsep, proses, apresiasi, analisis, realisasi, dan evaluasi desain dalam pengembangan karya seni rupa dan kriya secara konstruktif dan kreatif.Penyusunan Penelitian Tindakan Kelas ini bertujuan untuk meningkatkan Kompetensi dasardasar desain pada Siswa Kelas X Paket Keahlian DKV SMK Negeri Pacitan, semester gasal Tahun pelajaran 2014/2015. Secara khusus penelitian ini bertujuan untuk: (1) Mendeskripsikan proses pembelajaran dasar-dasar desain pada paket keahlian DKV (2) Mengetahui efektifitas pembelajaran berbasis Joyfulll Learning dalam meningkatkan kompetensi dasar-dasar desain pada siswa kelas $\mathrm{X}$ paket keahlian DKV SMK Negeri Pacitan. Penelitian dilaksanakan dalam dua siklus, di mana masing-masing-masing siklus terdiri dari tahap perencanaan, pelaksanaan, pengamatan, dan refleksi. Siklus I terdiri dari empat pertemuan, demikian pula halnya dengan Siklus II. Data hasil penelitian diperoleh melalui praktek menggambardasar-dasar desain yang meliputi desain 2 dan 3 dimensi serta lembar pengamatan siswa. Hasil penelitian siklus 1 menunjukkan bahwa dari jumlah 27 siswa yang sudah memperoleh nilai kriteria ketuntasan minimal/KKM 80 baru sejumlah 7 siswa atau $35 \%$ dari ketercapaian hasil pembelajaran. Rata-rata nilai pada evaluasi formatif tersebut adalah 76,6.Data obeserver diperoleh skor 3,32 yang termasuk dalam katagori Baik. Hasil penelitian Pembelajaran berbasis Joyfulll Learning pada siklus 2 diperoleh data dari jumlah 27 siswa seluruhnya sudah memenuhi KKM yang telah ditentukan. Rata-rata nilai pada evaluasi formatif tersebut adalah 83,2. Data obeserver diperoleh skor 3,91 yang termasuk dalam katagori Sangat Baik. Berdasarkanhasil penelitian maka hipotesis yang menyatakan bahwa Pembelajaran Berbasis Joyfulll Learning sangat efektif dalam meningkatkan meningkatkan kompetensi dasar-dasar desain pada siswa kelas X paket keahlian DKV SMK Negeri1 Pacitan terbukti kebenarannya sehingga tidak perlu dilanjutkan pada siklus berikutnya.
\end{abstract}

Kata Kunci: Efektifitas, Kompetensi, Desain.

\section{PENDAHULUAN}

Pembelajaran merupakan proses ilmiah dan diyakini sebagai titian emas yang mengembangan sikap, keterampilan, dan pengetahuan peserta didik. Pendekatan scientefic merupakan konsep belajar yang membantu guru mengaitkan antara materi yang diajarkan dengan situasi dunia nyata siswa dan mendorong siswa membuat hubungan antara pengetahuan yang dimilikinya dengan penerapannya dalam kehidupan mereka sebagai anggota keluarga dan masyarakat. Dengan konsep itu, hasil pembelajaran diharapkan lebih bermakna bagi siswa. Proses pembelajaran berlansung alamiah dalam bentuk kegiatan siswa bekerja dan mengalami, bukan mentransfer pengetahuan dari guru ke siswa. Strategi pembelajaran lebih dipentingkan sehingga akan memperoleh hasil yang diinginkan.

Kurikulum 2013 menekankan pada dimensi pedagogik modern dalam pembelajaran, yaitu menggunakan pendekatan ilmiah. Pendekatan ilmiah (scientific approach) dalam pembelajaran sebagaimana dimaksud meliputi mengamati, menanya, mencoba, mengolah, menyajikan, menyimpulkan, dan mencipta untuk semua mata pelajaran. Untuk mata 
pelajaran, materi, atau situasi tertentu, sangat mungkin pendekatan ilmiah ini tidak selalu tepat diaplikasikan secara prosedural.(Handout Kurikulum 2013)

Sikap tidak hanya diajarkan secara verbal, tetapi melalui contoh dan teladan. Proses pembelajaran tersebut merupakan ciri dari pendekatan scientefic. Pendekatan scientefic merupakan konsep belajar yang membantu guru mengaitkan antara materi yang diajarkan dengan situasi dunia nyata siswa dan mendorong siswa membuat hubungan antara pengetahuan yang dimilikinya dengan penerapannya dalam kehidupan mereka sebagai anggota keluarga dan masyarakat. Dengan konsep itu, hasil pembelajaran diharapkan lebih bermakna bagi siswa.

Zaini, dkk. (2004) menyatakan bahwa pembelajaran aktif adalah suatu model pembelajaran yang menempatkan siswa sebagai pusat dari proses belajar. Konsep pembelajaran aktif lebih memfokuskan kegiatan belajar pada peserta didik (siswa) dan pengajar (guru) lebih berperan sebagai fasilitator dan motivator. Melalui pembelajaran aktif guru memotivasi siswa agar selalu berusaha belajar dari berbagai sumber secara mandiri dengan demikian proses pembelajaran akan berlansung alamiah dalam bentuk kegiatan siswa bekerja dan mengalami, bukan mentransfer pengetahuan dari guru ke siswa.

Mengajar menurut Nana Sudjana (1992) merupakan suatu proses, yaitu proses mengatur, mengorganisasi lingkungan yang ada di sekitarsiswa sehingga dapat menumbuhkan dan mendorong siswa melakukan proses belajar.

Terkait dengan wacana di atas sekolah menengah kejuruan (SMK) yang merupakan sekolah dengan berorientasi pada dunia kerja, berupaya memberikan pembelajaran bekal siap kerja pada siswa sebagai tenaga kerja yang terampil tingkat menengah sesuai dengan persyaratan yang dituntut oleh dunia kerja. Kegiatan belajar mengajar pada tingkat sekolah menengah kejuruan diarahkan untuk membentuk kemampuan siswa dalam mengembangkan perolehan belajarnya baik pada aspek pengetahuan, keterampilan, dan tata nilai aspek sikap guna menunjang pengembangan potensinya.

Sekolah Menengah Kejuruan bertujuan untuk :

1. Mewujudkan lembaga pendidikan kejuruan yang akuntabel sebagai pusat pemberdayaan kompetensi berstandard internasional.

2. Mendidik SDM yang punya etos kerja dan berkompetensi dengan standar internasional.

3. Memberikan berbagai layanan pendidikan kejuruan yang variable dan fleksibel dan terintegrasi antar jalur dan jenjang pendidikan.

4. Menjamin kelangsungan penyelenggaraan pendidikan sesuai kebutuhan masyarakat.

5. Mengoptimalkan sumber daya pendidikan untuk meningkatkan layanan dan mutu pendidikan kejuruan.

Paket Desain Komuikasi Visual sebagai salah kompetensi keahlian di SMK Negeri Pacitan, berupaya meningkatkan kualitas dan hasil pembelajaran dengan mencari metode pendekatan yang tepat untuk diimplementasikan pada siswa agar dapat menghasilkan lulusan yang dapat diandalkan dan menjadi siswa mandiri, 
berjiwa wirausaha dan kreatif sesuai dengan bidang ilmu yang dimiliki.

Terkait dengan hal di atas maka salah satu Paket Keahlian yang ada di SMK Negeri Pacitan yaitu Desain Komunikasi Visual siswa diberikan materi untuk memahami elemen desain yang terdiri dari garis, bidang, ruang, bentuk, warna, tekstur dwimatra. (Wucius Wong 1996)

Dari observasi yang dilakukan peneliti khususnya pada pembelajaran menghasilkan elemen-elemen seni rupa organik dan non organik, dalam bentuk 2 D dan 3 D, material, simetris dan asimetris, dari alam dan buatan, komposisi, fungsi, manfaat, pelestarian dan penggabungan yang terkait dengan penciptaan karya/ desain khususnya pada praktek menggambar gradasi warna masih terdapat kelemahan dari segi pembelajaran dan kemampuan menguasai materi yang diajarkan oleh Guru. Dalam hal ini siswa belum menunjukkan hasil pembelajaran yang signifikan sehingga perlu diupayakan pendekatan yang efektif agar hasil belajar yang dimaksud dapat lebih meningkat secara maksimal.

\section{METODE PENELITIAN}

Setting dalam penelitian ini adalah di lembaga pendidikan SMK Negeri PacitanPaket Keahlian Desain Komunikasi Visual.

Penelitian Tindakan Kelas ini dilaksanakan pada bulan Juli sampai dengan bulan Desember 2014 pada semester gasal tahun pelajaran 2014/2015 dan disesuaikan dengan jadwal mengajar kompetensi dasar-dasar desain kurikulum 2013. Bertindak sebagai Observer dalam PTK ini adalah rekan Guru DKV yaitu
Drs. Rochmat Kundarto MM.Pd dan Bayuningsih Setyo Rini S.Pd.

Subyek penelitian adalah siswa kelas $X$ Paket Keahlian Desain Komunikasi Visual SMK Negeri Pacitan yang pada tahun pelajaran 2014/2015 berjumlah 27 peserta didik dengan rincian Putra 20 orang dan Putri 7 orang.

Instrumen yang digunakan dalam penelitian ini terdiri dari :

1. Silabus

Yaitu pedoman pembelajaran Kompetensi Dasar-dasar desain, kurikulum 2013 yang mencakup kompetensi dasar, materi pokok, pembelajaran, penilaian, alokasi waktu dan sumber belajar.

2. Rencana Pelaksanaan Pemelajaran (RPP)

Yaitu administrasi atau seperangkat pembelajaran yang digunakan sebagai acuan guru dalam mengajar. Dalam penelitian ini Rencana Pelaksanaan Pemelajaran disusun sebanyak 2 siklus.

3. Lembar Kegiatan Siswa

Lembar kegiatan siswa ini dipergunakan untuk pengumpulan data siswa dalam proses pembelajaran.

4. Lembar Observasi Kegiatan Belajar Mengajar

Lembar observasi pembelajaran untuk mengamati kemampuan guru dalam mengelola pembelajaran.

5. Lembar observasi aktivitas siswa untuk mengamati aktivitas siswa selama proses pembelajaran.

Prosedur penelitian ini terdiri dari empat komponen, meliputi: Perencanaan (planning), tindakan (acting), Pengamatan (observing), dan refleksi (reflecting).

Sumber data dalam Penelitian Tindakan Kelas ini diperoleh dari : 
1. Evaluasi yang berupa penilaian secara kuantitatif terhadap hasil karya siswa.

2. Penilaian praktekmenggambar gradasi warna.

3. Lembar kegiatan guru yang merupakan hasil pengamatan Observer selama pembelajaran.

4. Hasil angket motivasi siswa.

Adapun metode dalam pengumpulan data dalam penelitian ini yaitu :

1. Metode Angket

Data yang diperoleh adalah dalam bentuk tulisan yakni jawaban dari responden. Pengisian angket dalam penelitian ini adalah responden kelas $\mathrm{X}$ paket Keahlian Desain Komunikasi Visual yang berjumlah 27 siswa. Sebelum mengisi angket terlebih dahulu peneliti menjelaskan mengenai maksud dan tujuan pengisian angket.

Angket yang digunakan dalam penelitian ini adalah angket langsung terbuka, artinya angket diberikan dan dijawab langsung oleh responden. Pertanyaan-pertanyaan dalam angket telah disediakan pilihan jawaban.

2. Metode Interview

Dari sumber data Person yang bisa memberi jawaban lesan melalui wawancara atau jawaban tertulis melalui angket (questionaire). Dalam hal ini peneliti mendapatkan data dengan menyusun beberapa pertanyaan.

3. Metode Dokumentasi

Yaitu peneliti melakukan pengambilan foto penelitian dengan obyek siswa kelas $\mathrm{X}$ dan hasil karya siswa paket Keahlian Desain Komunikasi Visual pada saat proses pembelajaran berlangsung.

Validasi data dalam penelitian ini dilakukan oleh 2 Observer yang merupakan Guru DKV SMK Negeri Pacitan.

Analisis data untuk mengetahui kualitas dan hasil pembelajaran menggunakan analisis deskriptif komparatif yaitu dengan membandingkan hasil pembelajaran berupa nilai rata-rata pada siklus I dan siklus II.

Sedangkan analisis data angket pembelajaran diolah dengan kriteria sabagai berikut: siswa yang menjawab setuju sekali (SS) diberi skor 4, setuju (S) diberi skor 3, kurang setuju (KS) diberi skor 2, dan tidak setuju (TS) diberi skor 1 . Data observasi proses pembelajaran guru dan siswa oleh observer diolah dengan kriteria sebagai berikut: aktivitas sangat tinggi diberi skor 4 , aktivitas tinggi diberi skor 3, aktivitas sedang diberi skor 2, dan aktivitas kurang diberi skor 1 .

Data yang sudah dikumpulkan kemudian dimasukkan dalam tabel dan dianalisis dengan penghitungan menggunakan program Exel sehingga data kuantitatif yang dihasilkan valid dan tepat.

Data-data untuk memperoleh hasil pembelajaran yaitu :

1. Nilai rata-rata prestasi siswa diperoleh dengan rumus sederhana yaitu :

$$
\bar{X}=\frac{\sum X}{\sum N}
$$

Dimana :

$\bar{X}=$ Nilai rata-rata

$\Sigma X=$ Jumlah semua nilai siswa

$\Sigma \mathrm{N}=$ Jumlah semua siswa

2. Ketuntasan belajar dengan rumus :

$$
P=\frac{\sum \text { Siswa.yang.tuntas.belajar }}{\sum \text { Siswa }} \times 100 \%
$$


Ukuran keberhasilan dalam penelitian tindakan kelas ini adalah meningkatnya kualitas dan nilai hasil pembelajaran siswa kelas $\mathrm{X}$ paket keahlian Keahlian Desain Komunikasi Visual kompetensi dasar-dasar desainbaik secara individu maupun secara klasikal.

Indikator Kinerjapada PTK dikatakan berhasil apabila hasil evaluasi kompetensi sekurang-kurangnya $95 \%$ siswa mengalami ketuntasan belajar. Dengan kata lain, $95 \%$ seluruh siswa siswa mencapai kriteria ketuntasan minimal (KKM) yang ditetapkan oleh sekolah. Dalam hal ini, KKM kompetensi dasar-dasar desain adalah 80. Indikator untuk hasil skor angket yang meliputi minat dan motivasi siswa dalam mengikuti proses pembelajaran harus dalam katagori baik.

\section{PEMBAHASAN}

Penelitian tindakan adalah sesuatu gerak kegiatan yang sengaja dilakukan dengan tujuan tertentu, yang dalam penelitian ini berbentuk rangkaian siklus kegiatan. (Suharsimi Arikunto, 2006).

PTK bertujuan untuk memperoleh bukti kepastian apakah terjadi perbaikan, peningkatan, dan atau perubahan sebagaimana yang diharapkan. Oleh karena itu ketika suatu PTK berhasil menunjukkan terjadinya perbaikan, peningkatan, dan atau perubahan sebagaimana yang diharapkan, maka berarti sekaligus peneliti (guru) telah berhasil menemukan model dan prosedur tindakan yang memberikan jaminan terhadap upaya pemecahan masalah tersebut.

Berdasarkan wacana di atas maka dalam penelitian tindakan kelas ini peneliti berupaya mengimplemenatsikan model pembelajaran yang efektif dalam rangka meningkatkan kemampuan dan keterampilan serta kompetensi produktif pada siswa.

Model pembelajaran yang dimaksud adalah meningkatkan kompetensi dasardasar desain melalui pendekatan Joyfull Learning paket keahlian DKV Kelas X, Semester 1 SMK Negeri Pacitan Tahun Pelajaran 2014/2015.

\section{Siklus 1 \\ Perencanaan}

Tahap ini peneliti memper-siapkan perangkat pembelajaran yang terdiri dari rencana pelak-sanaan pemelajaran (RPP), format penilaian, lembar observer dan alatalat penga-jaran yang mendukung.

Kompetensi dasar-dasar desain difokuskan pada materi menggambar gradasi warna yang merupakan salah satu pembelajaran tersebut. Adapun proses pembela-jaran adalah sebagai berikut :

1) Siswa menyiapkan alat dan bahan berupa: kertas gambar A 3, pinsil, penghapus, penggaris, cat air, kuas cat air no : 1, 3, 5 dan 7

2) Siswa mengerjakan tugas menggambar gradasi dengan langkah langkah sebagai berikut :

3) Membuat bidang garis secara vertikal dan horizontal pada bidang gambar dengan ukuran $3 \times 10 \mathrm{~cm}$, kemudian diberi garis batas $1 \mathrm{~cm}$.

4) Mempersiapkan peralatan yang akan dgiunakan yaitu Cat poster, kuas, palet, kain lap, air, peng-garis.

5) Langkah selanjutnya, siswa memberi warna sesuai dengan warna yang gradasi yang dipilih. 
6) Terakhir, siswa memberi iden-titas dan tanda tangan pada kolom yang dibuat, maka selesailah pekerjaan siswa.

7) Kriteria penilian pada poin teknik sapuan kuas, pewarnaan, keindahan (estetika), dan kerapihan

\section{Kegiatan dan Pelaksanaan}

Pelaksanaan kegiatan belajar mengajar untuk siklus I dilaksana-kan pada bulan September 2014 di Kelas X, semester 1,paket keahlian DKV, dengan jumlah sampel 27 siswa. Dalam hal ini peneliti ber-tindak sebagai guru. Adapun proses belajar mengajar mengacu pada rencana pelajaran yang telah dipersiapkan. Observasi dilaksana-kan bersamaan dengan pelaksaaan belajar mengajar. Setiap siswa diberikan contoh gambar teknik gradasi untuk digambar secara manual pada bidang gambar ukuran A 4 . Selama proses pembelajaran peneliti mengamati dan memberi arahan dalam menggambar teknik gradasi. Sedangkan observer mengamati dan mencatat proses pengajaran yang dilakukan oleh peneliti. Pelaksanaan pembelajaran berlangsung selama 9 jam dengan alokasi 1 jam ádalah 45 menit.

Akhir proses belajar mengajar seluruh karya siswa dikumpulkan dan diberi penilaian. Masing-masing karya dievaluasi untuk ditunjukkan kekurangan dan kelemahan dalam menggambar gradasi sehingga siswa dapat memperbaiki pada tugas-tugas berikutnya. Dengan demikian peroses pembelajaran tersebut dapat diketahui tingkat keber-hasilan siswa dalam proses belajar mengajar yang telah dilakukan.

Unsur-unsur penilaian meng-gambar gradasi meliputi Teknik sapuan kuas,
Pewarnaan, Kein-dahan (estetika) dan Kerapihan. Dari proses pembelajaran diperoleh data evaluasi menggambar gradasi warna pada siklus 1 secara klasikal jumlah nilai yaitu 82,68 dengan rata-rata nilai :76,6, yang berarti belum memenuhi standar nilai KKM yaitu 80.Ketuntasan belajar mencapai $25 \%$ atau ada 7 siswa dari 20 siswa yang sudah tuntas belajar.

\section{Refleksi}

Dalam pelaksanaan kegiatan belajar mengajar diperoleh data hasil pengamatan sebagai berikut:

1) Guru sudah baik dalam me-motivasi siswa dan dalam menyampaikan tujuan pembela-jaran

2) Guru sudah baik dalam pengelolaan waktu

3) Antusias Siswa sudah baik selama pembelajaran berlang-sung

4) Nilai KKM secara klasikal belum tuntas

Pelaksanaan kegiatan belajar mengajar pada siklus I ini masih terdapat kekurangan yaitu nilai KKM secara klasikal belum tuntas sehingga perlu adanya revisi untuk dilakukan pada siklus berikutnya dengan langkah-langkah sebagai berikut:

1) Guru perlu lebih terampil dalam memotivasi siswa dan lebih jelas dalam menyampaikan tujuan pembelajaran. Dimana siswa diajak untuk terlibat langsung dalam setiap kegiatan yang akan dilakukan.

2) Guru perlu mendistribusikan waktu secara baik dengan me-nambahkan informasi-informasi yang dirasa perlu dan memberi catatan

3) Guru harus menerapaka model pembelajaran yang lebih efektif dan 
tepat agar nilai KKM klasikal dapat mencapai ketuntasan $100 \%$.

\section{Siklus 2}

\section{Perencanaan}

Pada tahap ini peneliti mempersiapkan perangkat pembela-jaran model joy full learning yang terdiri dari rencana pelaksanaan Pelajaran, Contoh-contoh gambar gradasi, format penilaian, lembar observer dan alat-alat pengajaran yang mendukung.

\section{Kegiatan dan Pelaksanaan}

Pelaksanaan kegiatan belajar mengajar untuk siklus II dilak-sanakan pada bulan Nopember di Kelas X paket keahlian DKV dengan jumlah sampel 27 siswa. Adapun pembelajaran yang diterapkan adalah dengan menggunakan model joy full learning dikarenakan pada pembe-lajaran sebelumnya meskipun $\mathrm{KBM}$ sudah berjalan dengan baik namun kesan pembelajaran masih tegang, membosankan dan siswa seperti tidak kerasan baik di kelas maupun dalam mengerjakan tugas. Oleh karena itu pada siklus berikutnya peneliti berupaya untuk menciptakan pembelajaran yang menyenangkan, mengasyikkan, menarik dan dapat merangsang motivasi siswa untuk mengikuti pembelajaran materi menggambar dengan teknik gradasi warna.

Langkah-langkah pembela-jaran joyfull learning adalah :

1) Memahami sifat yang dimiliki siswa

Peneliti mendorong kepada seluruh siswa bahwa masing-masing siswa memiliki bakat yang dapat dilatih secara konsisten dalam pembelajaran produktif kria kulit. Peneliti mengambil contoh mengenai orang-orang sukses yang dahulu-nya adalah orang miskin, tidak berbakat, sering disepelekan orang dan ternyata sekarang menjadi orang terkenal yang penuh dengan daya cipta dan daya kreatif yang dapat memberi inspirasi bagi semua orang.

2) Mengenal siswa secara per-orangan

Peneliti melakukan pende-katan pribadi kepada seluruh siswa dan menanyakan kesulitan apa yang dimiliki dalam mengikuti pembelajaran sekaligus memberikan solusinya.

3) Mengembangkan kemampuan berpikir kritis, kreatif, dan ke-mampuan memecahkan masalah.

Dalam hal ini peneliti memberi tugas menggambar teknik gradasi warna dengan mengambil warna primer untuk kemudian semua siswa diberi kesempatan melakukan eksplorasi gradasi. Siswa yang kreatif dan mampu mengatasi permasalahan dalam membuat gradasi warna yang telah ditentukan akan diberi reward dengan pujian dan karyanya dipasang di kelas.

4) Mengembangkan ruang kelas sebagai lingkungan belajar yang menarik.

Peneliti memberi kesem-patan kepada siswa untuk memajang karyanya di kelas kemudian seluruh siswa diminta untuk memberikan apresiasinya. Dengan teknik ini suasana kelas menjadi meriah dan menyenang-kan.

5) Memanfaatkan lingkungan seko-lah sebagai sumber belajar.

Dalam hal ini peneliti mendiskusikan bagaimana sebaik-nya warna dinding di kelas, dinding sekolah, ruang guru, aula dan lain sebagainya. 
Apakah perlu diberi sentuhan gradasi warna dan warna apa yang sesuai dengan lingkungan sekolah. Sambil mengerjakan tugas masing-masing siswa kemudian memberikan pendapat dan komentar dan kemudian peneliti memberikan umpan balik yang baik untuk meningkatkan kegiatan belajar.

Pelaksanaan pembelajaran joyfull learningberlangsung selama 9 jam dengan alokasi 1 jam ádalah 45 menit $4 \mathrm{x}$ tatap muka. Pada akhir proses belajar mengajar seluruh karya siswa dikumpulkan dan diberi penilaian. Masing-masing karya dievaluasi untuk ditunjukkan kekurangan dan kelemahan dalam menggambar teknik gradasi agar dapat diketahui tingkat keberhasilan siswa dalam proses belajar mengajar yang telah dilakukan.

Hasil pembelajaran dengan model joyfull learning ternyata berpengaruh positif bagi peningkatan kompetensi dasar-dasar desain pada siswa kelas $\mathrm{X}$ paket keahlian DKV. Antusias siswa dalam mengikuti pembelajaran sangat baik, suasana kelas menjadi lebih hidup dan tidak membosankan. Tugas-tugas yang diberikan kepada siswa dapat dikerjakan dengan baik. Hasil karya siswa menjadi lebih rapi, teliti dan estetis.

Nilai atau hasil belajar siswa pada materi ini menunjukkan peningkatan yang signifikan dan ketuntasan belajar secara klasiklal dapat tercapai hingga $100 \%$. Dengan demikian pembelajaran dengan model joy full learning dapat terlaksana dengan baik dan memuaskan.
Data evaluasi menggambar teknik gradasi warna pada siklus 2 tersebut maka dapat dianalisis dengan penghitungan sederhana menggunakan program microsoft excel yaitu: (1) Nilai rata-ratanya 83,2 (2) Ketuntasan Belajar $100 \%$.

Hasil ini menunjukkan bahwa pada siklus II ini ketuntasan belajar secara klasikal sudah memenuhi standar nilai KKM yaitu 80 . Pengamatan yang dilakukan oleh 2 rekan observer diperoleh hasil rata-rata skor pembelajaran menggambar gradasi warna pada siklus 2 sebesar 3,91 yang termasuk dalam kriteria sangat baik.

\section{Refleksi}

Dalam pelaksanaan kegiatan belajar mengajar diperoleh data hasil pengamatan sebagai berikut:

1) Guru sudah sangat baik dalam memotivasi siswa dan dalam menyampaikan tujuan pembelajaran.

2) Guru juga sudah sangat baik dalam pengelolaan waktu.

3) Siswa sangat antusias selama pembelajaran berlangsung.

Pelaksanaan kegiatan belajar mengajar pada siklus II dengan menerapkan model joy full learning pada kompetensi dasar-dasar desain kelas $\mathrm{X}$ paket keahlian DKV se-mester 1 menunjukkan peningkatan hasil belajar yang sangat signifikan, seluruh siswa sudah mencapai nilai KKM sehingga pembelajaran dengan model joy full learning dapat dikatakan berhasil dengan baik dan memuaskan. 


\section{KESIMPULAN}

Dari hasil kegiatan pembelajaran yang telah dilakukan selama dua siklus, dan berdasarkan seluruh pembahasan serta analisis yang telah dilakukan dapat disimpulkan yaitu pembelajaran kompetensi dasar-dasar desain berbasis Joyfull Learning memiliki dampak postif dalam meningkatkan kompetensi pembelajaran yang ditandai dengan peningkatan ketuntasan belajar siswa yang dibuktikan pada sikulus dua, yaitui seluruh siswa dapat mencapai nilai standar lulus.

Berdasarkan hasil analisis data pada siklus I belum ada perubahan nilai yang signifikan. Peningkatan pemahaman siswa pada tiap siklus diikuti dengan perubahan tingkah laku siswa ke arah yang positif. Hal tersebut terlihat pada keaktifan dan respon siswa dalam menerima pembelajaran sangat antusias, siswa merasa senang dan tertarik dalam mengikuti pembelajaran dengan metode Joyfull Learning.

Dengan metode Joyfull Learning siswa tertarik dan termotivasi untuk meningkatkan kompetensi dasar-dasar desain dengan lebih baik.

\section{Saran-Saran}

Pendekatan berbasis Joyfull

Learning memerlukan persiapan yang cukup matang, sehingga guru harus mampu menentukan atau memilih topik yang benar-benar bisa diterapkan untuk memperoleh hasil pembelajaran yang optimal.

Dalam rangka meningkatkan kemampuan kompetensi dasar-dasar desain, guru hendaknya lebih sering melatih siswa dengan kegiatan eksplorasi, dimana siswa nantinya dapat menemukan pengetahuan baru, memperoleh konsep dan keterampilan, sehingga siswa berhasil atau mampu memecahkan masalahmasalah yang dihadapinya.

\section{DAFTAR PUSTAKA}

Arikunto, Suharsimi. 2006. Prosedur Penelitian Suatu Pendekatan Praktek. Jakarta: Rineksa Cipta.

Bahan Ajar Dasar Kekriaan untuk SMK, 1998.Menggambar Teknik gradasi Geometris, Direktorat Pendidikan Menengah Kejuruan, Dep. P dan K Djamarah, Syaiful Bahri. 2002. Strategi Belajar Mengajar. Jakarta: Rineksa Cipta

Direktorat Pembinaan Sekolah Menengah KejuruanDirektorat Jenderal Pendidikan MenengahKementerian Pendidikan Dan Kebudayaan2014, Handaout Pendampingan Implementasi Kurikulum 2013.

Kurikulum 2013, Kemendikbud Jakarta

Sudjana, Nana 2005. Penilaian Hasil Proses Belajar Mengajar, Bandung, PT Remaja Rosdikarya

Nirmana dalam desain grafis, 2009 By Lizard Wijanarko on September 1, Wagiono, Msc, Drs, 1998, Latihan Menggambar Dasar Bentuk dan Warna, Mandira Jaya Abadi.

Wong,Wucius 1996. Beberapa Asas Merancang Dwimatra. Bandung: ITB. Zaini, Hisyam, Bermawy Munthe, \& Sekar Ayu Aryani. (2004). Strategi Pembelajaran Aktif. Yogyakarta: CTSD IAIN Sunan Kalijaga 